\title{
Hellenistic Period Regal Coins in Elmalı Museum
}

\author{
[ELMALI MÜZESİ'NDEKİ HELLENİSTİK DÖNEM KRALİ SİKKELERİ]
}

\author{
Ömer TATAR
}

\author{
Anahtar Kelimeler \\ Elmalı Müzesi, Hellenistik Dönem, Krali Sikkeler. \\ Keywords \\ Elmalı Museum, Hellenistic Period, Regal Coins.
}

\section{ÖZET}

Antalya'nın Elmalı ilçesinde yer alan Elmalı Müzesi, antik dönemde Milyas ve Kabalis'i Lykia'ya bağlayan yol güzergahı üzerindedir. Elmalı'nın stratejik konumu nedeniyle, bilhassa müze koleksiyonunda yer alan Hellenistik dönem krali sikkelerin sunacă̆ı numismatik veriler önemlidir. Müze envanterinde toplam 506 sikke yer almaktadır ve bunların 472'si gayri Islamidir. Koleksiyonda yer alan Hellenistik dönem krali sikkelerin sayıs ise 32'dir. Bunlar içerisinde Makedon, Ptolemaios, Seleukos ve Lysimakhos darpları yer alır. Söz konusu malzeme Hellenistik dönem krallıklarının bölgedeki varlıklarının açık bir yansımasıdır. Anadolu müzelerinde yer alan yayınlanmamış numismatik malzeme hem az bilinen hem de daha önce bilinmeyen örnekleri literatüre tanıtması bağlamında önem arz eder ve bu çerçevede Elmalı Müzesi'nde yer alan Hellenistik döneme ait krallık sikkeleri de mevcut atıfların gözden geçirilmesi ve değerlendirilmesine olanak sağlamaktadır. Bu çalışmada söz konusu müze malzemesi tarihi arka planı ile birlikte ele alınmaktadır.

\begin{abstract}
Elmall Museum, located in the district of Elmall of Antalya, is on the route which connected Milyas and Cabalis to Lycia in antiquity. Due to Elmali's strategic location, potential data to be presented by the coins, particularly Hellenistic period regal issues, in the museum collection is significant. Museum inventory records 506 coins in total and 472 coins are dated to pre-Islamic periods. In museum collection, there are 32 Hellenistic period regal coins. They include Macedonian, Ptolemaic, Seleucid and Lysimachus coins. The material clearly reflects the Hellenistic kingdom's existence over the region. Anatolian museums' unpublished numismatic materials have importance for presenting rare or previously unknown specimens to the numismatic literature, Hellenistic period's regal issues in Elmals Museum help us review existing attributions and reexamine unattributed issues. In this study, coins in museum collection are introduced and presented with historical background.
\end{abstract}

Elmalı Museum is located in the district of Elmal1, about $110 \mathrm{~km}$ southwest of Antalya, Turkey. The museum building, which was built in 1941, was used as Government Office until 1987. Before it was restored and reopened as museum in 2011, it served as Tax Office and Teacherage. ${ }^{1}$ Museum collection covers artefacts found in and around Elmalı which has been unceasingly inhabited since Neolithic Age. ${ }^{2}$ Elmal1, named as Akarassos in antiquity,

1 Yener 2011.

2 Artefacts found in Karataş-Semahöyük, Karaburun, Kızılbel and Bayındır Tumuluses, Hacımusalar and its vicinity is located in Milyas region which lies beyond Lycia's northern frontier. ${ }^{3}$ Although it is known that this vast plain between Beydağları (Masikytos), Akdağlar (Kragos) and Susuz Dağ was a part of Lycia region in Hellenistic period, in broad terms, it was a settlement area of a common culture affected by Milyas, Cabalis, Pisidia and Phrygian culture. Elmal1 was on the route which connected Milyas and Cabalis to Lycia and as Elmalı's

Mound and Karaçakır and Arykanda (a Lycian city) excavations are exhibited in the museum sections.

3 Çevik 2015: 267-268. 
strategic location, which is rooted in this fact, is taken into consideration, importance of the potential data to be presented by the coins in the museum collection increases.

Museum inventory records 506 coins in total. ${ }^{4}$ 34 of them belong to Islamic period while 472 coins are dated to pre-Islamic periods. Subject of this study is the Hellenistic period's regal coins, and it aims both to present the material and to see the reflections of the Alexander the Great's conquest of Asia Minor and the power struggle occurred in Asia Minor ${ }^{5}$ afterwards through the coins in the museum.

In museum collection, there are 32 Hellenistic period regal coins. 15 are Macedonian, 9 are Ptolemaic, 7 are Seleucid and 1 is Lysimachus issues. While 13 coins are of silver, 19 are of bronze. All of the coins were included in the collection through purchase, donation or confiscation.

Out of 15 Macedonian regal coins in the collection, 10 are silver issues. 7 are tetradrachms, one is hemidrachm. Mints of attributable coins are Amphipolis (3 pcs.), Abydos (1 piece), Magnesia ad Maeandrum? (1 piece), Miletos (1 piece), Salamis (1 piece) and Byblos (1 piece). First specimen (Cat. No. 1) struck at Amphipolis, which kingdom's most important mint in Macedonia along with Pella, belongs to Alexander the Great's reign and it is dated to 336-323 BC. Other two coins struck there (Cat. No. 2-3) and the one struck at Abydos in Troad are dated to 315-294 BC. and 310-301 BC. respectively (Cat. No. 4). These are posthumous Alexander issues. Another posthumous coin (Cat. No. 5) is probably an issue from Magnesia ad Maeandrum and it is dated to 319-305 BC. On the other hand, the issue struck at Miletos in Ionia is dated to 325-323 BC., while the coin which is attributed to Salamis on Cyprus is dated to 332-323 BC (Cat. No. 6; 11 (probably a modern-day imitation). Finally, the last example (Cat. No. 12) is from Byblos in Phoenicia and dated to $330-320 \mathrm{BC}$

4 Some of the artefacts in the museum inventory were transferred from the Antalya Archaeology Museum collection to this new museum.

5 For detailed information about the period named Diodokhoi see. Hammond 1992: 250-294; Bosworth 2005: 215-224.
When it comes to 5 bronze coins, 3 are hemiobol and 2 are dikhalkon. All of these issues are of Asia Minor origin. Mints are Uncertain Western Asia Minor (3 pcs.), Miletos (1 piece) and Mylasa (1 piece). First 3 specimens (Cat. No. 8-10), which are yet to be attributed firmly to any mint but known to be of Asia Minor origin and classified under the title "Uncertain Western Asia Minor" in numismatic literature, are dated to 323-310 BC. Other coin (Cat. No. 7), attributed to Miletos, is dated to 323-319 BC. The last specimen (Cat. No. 13) is the coin struck by Eupolemos, who is thought to be put in charge of Caria region by Macedonian king Kassandros $^{6}$, and it is dated to 315-313 BC. ${ }^{7}$

Another Hellenistic period kingdom of which coins are registered in the museum collection is Ptolemaic Kingdom. As it is known, after the death of Alexander the Great, Antigonos Monophthalmos ruled a large proportion of the Asia Minor until the Battle of Ipsos in 301 BC. and Ptolemaic kingdom achieved dominance over Caria, Lycia, Pamphylia and Cilicia in the reign of Ptolemy II Philadelphus (282-246 BC.). ${ }^{8}$

In the museum collection, there are 9 Ptolemaic coins which indicate Egyptian dominance. All of them are bronze and their mints are Alexandreia (3 pcs.), Telmessos (3 pcs.), Kaunos (2 pcs.) and Palai Paphos (1 piece). The Palai Paphos issue (Cat. No. 24) belongs to the reign of Ptolemy I Soter (305-282 BC.) and it is dated as after 294 BC. 3 bronzes, which are attributed to Alexandreia, the capital of the kingdom, are attributed to the period of Ptolemy II Philadelphus. Among them, earliest coins (Cat. No. 25-26) are dated to $275 / 274$ BC. while the other coin (Cat. No. 27) is dated to 260s BC. Other 5 coins are of Asia Minor origin. These coins (Cat. No. 28-32), all of which are dated to Ptolemy III Euergetes (246-222 BC.), are attributed to Carian cities Kaunos and Telmessos, although it is not a certain attribution yet. ${ }^{9}$

6 On Eupolemos see. Descat 1998; Fabiani 2009. For the hypothesis that Eupolemos was a governor/dynast who ruled a part of Caria, see. Fabiani 2009.

7 For Eupolemos' coins see. Wroth 1891; Akarca 1959; Descat 1998: 170-175.

8 For the Ptolemaic hegemony in Asia Minor, see. Bagnall 1976: 80-116; Meadows 2012; Grabowski 2019.

9 See. CPE: 103-106. 
Svoronos attributed the coins with trident to Berytos and that with tripod to Ptolemais (Ake). Ashton, based on Fethiye Museum collection, firstly suggested Telmessos ${ }^{10}$ and then Kaunos ${ }^{11}$ as possible mints for either one or both of these coins. Then, Konuk, who published the Ptolemaic coins in Bodrum Underwater Museum and agreed with Ashton, confirmed the southwest Asia Minor origin without specifying a certain mint. ${ }^{12}$ Lorber, on the other hand, classified trident bronzes under the title "Probably Caunus" and attributed tripod bronzes to Telmessos. ${ }^{13}$ Her main basis for the Telmessos attribution is the numerical density in Fethiye Museum and the specimens in Isparta Museum that is closer to Telmessos than to Kaunos. On the other hand, Lorber agrees with Ashton on trident bronzes' attribution to Kaunos, although with little hesitation, based on the holdings of Fethiye Museum. It seems almost certain that these two bronze series are from southwest Asia Minor as suggested by museum collections. However, for a certain mint attribution, excavation data is to play a significant role. Such numismatic data will either confirm existing attributions or make a new mint attribution possible.

Seleucid Kingdom always had the intention to assume dominance over Asia Minor. After the death of Lysimachus, the kingdom ruled the interior territories from Halys in northeast to Sangarios in northwest at intervals, between 281-197 BC. As a result of Antiochus III Megas' Asia Minor campaign (198-193 BC.), coastal regions, which were ruled by Ptolemies in that period, came under the rule of Seleucids.14 Total number of Seleucid coins in the Elmalı museum collection is 7.2 coins are of silver and 5 coins are of bronze. First of the attributable silver coins (Cat. No. 19) is dated to the period of Seleucus II Callinicus. This issue's mint is classified as "Uncertain Mint, Western", as it is yet to be attributed to any specific mint. On the other hand, the iconography of the other issue (Cat. No. 23) is not clearly visible due to slipped

10 Ashton 2002: 10.

11 Ashton 2004: 46.

12 Konuk 2004, p. 174. Nevertheless, Konuk uses Svoronos' attribution in his catalogue.

13 CPE: 104. Also see. Cavagna 2015: 294-298.

14 Ma 1999: 82-90; Alten 2015: 83-87. die. However, due to the head of Antiochus I on the obverse side, it is possible to suggest a date during the reign of Antiochus I Soter (281-261 BC.).

When it comes to the bronze coins, among 5 specimens, 4 are attributed to Sardeis and 1 to Antioch on the Orontes. Among Sardeis issues, one belongs to Antiochus II and other to Seleucus II and they are dated to 261-246 BC. and 246-242 BC. respectively (Cat. No. 17-18). Other two coins (Cat. No. 20-22) which were struck in Sardeis, and Antioch on the Orontes are the issues of Antioch III Megas' reign and dated to $197-187 \mathrm{BC}$.

Kingdom of Lysimachus (Thracian Kingdom) is the last kingdom whose coin exists in the museum collection. Commander Lysimachus became king in 306/305 BC. and following the Battle of Ipsos in 301 BC. he managed to expand his territories and started to rule as far as Halys. ${ }^{15}$ This coin (Cat. No. 16) is a posthumous issue, dated to 260-late 250s BC., struck in the name of Lysimachus ${ }^{16}$ and it was minted in Cius, Bithynia where Lysimachus had partial control after 289 BC. 17

When the statistic of these coins in Elmalı Museum is produced, it is seen that $47 \%$ of them are Macedonian regal issues followed by $28 \%$ Ptolemaic coins and 22\% Seleucid coins while the single Lysimachus coin covers 3\% of the total. 18 Thanks to Davesne's article "La Circulation Monetaire en Pisidie a L'Epoque Hellenistique" published in 2002 which examines the Hellenistic period coin circulation in Pisidia region, it is possible for us to see a similar statistic and make a comparison. In this work, Davesne comparatively reviews the material in Yalvaç Museum in Pisidia and Silifke Museum in Cilicia. According to this study, among Hellenistic period regal coins in Yalvaç Museum $68 \%$ are Macedon, $18 \%$ are Seleucid, $1,5 \%$ are Ptolemaic while 12,5 are other kingdoms' coins. In Silifke Museum, 43\% are

15 For Lysimachus' dominance over Asia Minor until the Battle of Corupedion in 281 BC., see. Lund 1992: 51-106.

16 For the regal coins which continued to be struck after Lysimachus' death and his kingdom's disappearance, see. Marinescu 2000; 2004.

17 See. Lund 1992: 105.

18 See the Graphic I. 
Macedon, 32\% are Seleucid, 16\% Ptolemaic and $8 \%$ are other kingdoms' coins. ${ }^{19}$ Just like Elmal1, majority of the coins in these museums are Macedonian regal coins which were struck both during and after the reign of Alexander and which are known to have circulated far and wide. Seleucid and Ptolemaic coins, on the other hand, follows a similar pattern and have second and third peak rates and they are found in museum collections depending on their domains.

When Elmalı coins are examined according to their metal, $41 \%$ are of silver and $59 \%$ are of bronze. ${ }^{20}$ It is known that silver coins, as they are of precious metal, circulate more and wider not only as a commercial medium but also due to military reasons. ${ }^{21}$ In this regard, it is very usual to see coins from distant mints such as Amphipolis, Cius and Byblos coins in Elmalı Museum. What matters more is bronze coins of which circulation is limited even when they are regal issues. ${ }^{22}$ Dense existence of bronze coins in a territory is a significant data to attest military units and garrisons as they are mostly given to soldiers for their daily needs. ${ }^{23}$ Almost all of the coins in museums are added to the collections either through purchasing or confiscation. For this reason, except a couple of specimens, we do not have information about their exact finding spots. It is a known fact that, due to legal concerns, people who bring the coins to the museums do not tell the real finding spot or give misleading information to responsible officials. Therefore, this material needs to be examined with caution. Although it might be insecure and specious to make mint

19 Davesne 2002.

20 In Yalvaç Museum: 62,4\% silver, 37,6\% bronze. In Silifke Museum: $17,7 \%$ silver, $82,3 \%$ bronze, see. Davesne 2002.

21 Callataÿ 2016: 259-260.

22 Robert 1966: 113-114.

23 For instance, Macedonian royal coins found in the excavations carried out in the Karamattepe necropolis area on the Nif Mountain in Ionia region confirm the Macedonian military presence in the region. A total of 81 coins were recovered during the excavations between 2006-2010, 43 of which are Macedon regal issues, see. Lenger 2013b. Patara in the Lycia region and Nagidos in the Cilicia region are settlements confirmed by numismatic data that they were cities with garrisons. For Patara, see. Lenger 2019a; For Nagidos, see. Tekin 2007. attribution based on numerical amount, it is still an affirmative evidence for coins' Asia Minor origin. Moreover, coins in Anatolian museums have importance for presenting rare or previously unknown specimens to the numismatic literature. Unfortunately, Hellenistic period regal coins in Turkey museums became subject of only a couple of academic studies. ${ }^{24}$ Future studies on these coins will not only present us with the material but also will make it possible to review existing attributions and reexamine unattributed or problematic issues. 25

\section{CATALOGUE}

\section{Macedonian Kingdom}

\section{Amphipolis}

336-323 BC.

Obv. Head of Herakles r., in lion skin

Rev. A $\Lambda E \Xi A N \triangle P[O Y]$. Zeus enthroned left, holding eagle on extended right hand and resting left on scepter, bucranium in left field

Price 1991, n. 93

1. AR $27 \mathrm{~mm} 16.67 \mathrm{gr} 2 \mathrm{~h}$

Inv. No. 2014-9 (Purchased)

\section{Amphipolis}

c. $315-294$ BC.

Obv. Head of Herakles r., in lion skin

Rev. A $\Lambda E \Xi A N \triangle P O Y$. Zeus enthroned left, holding eagle on extended right hand and resting left on scepter, $\Lambda$ in left field, torch below it

24 For the Macedonian Kingdom, see. Ashton 1998; Tatar 2016. For the Ptolemaic Kingdom, see. Ashton 2002; Konuk 2004. For the Kingdom of Bithynia, see. Güney 2017. For the Kingdom of Thrace, see. Yağ1z 2016; For the Kingdom of Lysimachus, see. Yağız 2014.

25 For instance, for the coinage attributed by Price (1991: n. 3158) to Salamis but re-attributed to Sardeis as a result of recent numismatic data, see. Lenger 2013a; Lenger-Tatar 2019: 65-66. Similarly, for another coin attributed to Western Asia Minor which was thought to be a Macedonian issue (Price 1991: n. P2), see. Lenger 2016; For the attribution of another regal issue (Price 1991: 2803) from Western Asia Minor to Tarsus mint, see. Lenger 2021. For the Asia Minor origin of Price 419A, see. Lenger 2019b. For the confirmation of Miletos-Mylasa origin of coins attributed to Kaunos by Ashton (2004), see. Lenger $2013 b$. 
Price 1991, n. 443

2. AR $26 \mathrm{~mm} 16.57 \mathrm{gr} 11 \mathrm{~h}$

Inv. No. 2014-15 (Purchased)

Rev. $[\mathrm{A}] \Lambda \mathrm{E} \Xi \mathrm{A}[\mathrm{N} \Delta \mathrm{POY}]$

3. AR $5 \mathrm{~mm} 16.86$ gr $3 \mathrm{~h} \mathrm{I}$

nv. No. 2014-8 (Purchased) Rev. A $A$ E $\Xi \mathrm{N} \Delta \mathrm{P}[\mathrm{OY}]$

\section{Abydos}

c. $310-301 \mathrm{BC}$.

Obv. Head of Herakles r., in lion skin

Rev. [A $\Lambda$ E $\Xi A N \Delta P[O Y]$. Zeus enthroned left, holding eagle on extended right hand and resting left on scepter, $\mathrm{M}$ in left field, $\Delta$ (not visible) beneath throne

Price 1991, n. 1560

4. AR $16 \mathrm{~mm}, 3.91 \mathrm{gr}, 11 \mathrm{~h}$,

Inv. No. 2012-51 (Purchased)

\section{Magnesia ad Maeandrum?}

c. 319-305 BC.

Obv. Head of Herakles r., in lion skin

Rev. A $\Lambda$ E $\Xi A N \Delta[P O Y]$ Zeus enthroned left, holding eagle on extended right hand and resting left on scepter, wreathed $\Lambda$ in left field

Cfr. Price, n. 1974 (variety: wreathed A, Magnesia ad Maeandrum, c. 319-305 BC.)

5. AR, 26 mm, 16.78 gr, 6h, Inv. No. 2014-10 (Purchased)

\section{Miletos}

c. 325-323 BC.

Obv. Head of Herakles r., in lion skin

Rev. A $\triangle E \Xi A N \triangle P[O Y]$. Zeus enthroned left, holding eagle on extended right hand and resting left on scepter, left field

Price 1991, n. 2090

6. AR $15.5 \mathrm{~mm}, 3.95 \mathrm{gr}, 12 \mathrm{~h}$,

Inv. No. 2014-44 (Purchased)

\section{Miletos}

c. 323-319 BC.

Obv. Head of Herakles r., in lion skin

Rev. A $\Lambda$ E $\Xi A N \triangle P O Y$. Bow in bowcase, club, wheat ear below

Price 1991, 281, n. 2102

Thompson 1983, 52, n. 149-56 (Miletos, c. 323-322 BC.)

Ashton 2004, 33-43 (Kaunos, c. 323-319 BC.)
7. AE 18 mm, 5.62 gr, 3h, Inv. No. 2015-8 (Donation)

(Note: These coins which were primarily attributed by Thompson (1983) and then by Price (1991) to Miletos, were attributed to Kaunos by Ashton in 2004 based on 29 specimens in Fethiye Museum. However, there is no example found in Kaunos excavations until today. ${ }^{26}$ On the other hand, there are 11 in İzmir Archaeology Museum, 10 in Ankara Museum of Anatolian Civilizations and 4 in Alanya Museum. Moreover, 2 were found in Laodikeia excavations. ${ }^{27}$ )

\section{Uncertain Western Asia Minor}

(c. 323-310 BC.)

Obv. Head of Herakles r., in lion skin

Rev. BA $\Sigma \mathrm{I} \Lambda \mathrm{E} \Omega \Sigma$. Bow in bowcase, club, torch below

Price 1991, n. 2799 (Uncertain Asia Minor, c. 323-310 BC.)

8. AE $0 \mathrm{~mm}, 5.32 \mathrm{gr}, 9 \mathrm{~h}$,

Inv. No. 2013-40 (Confiscated)

(Note: In Winterthur catalogue (1987) these coins are for the first time classified under the title "Asia Minor" and then Price (1991, n. 2799-2800) put them among "Uncertain Western Asia Minor". Still, a certain mint attribution has not been made. There are 25 in İzmir Archaeology Museum, 8 in Ankara Museum of Anatolian Civilizations and 3 in Afyon Museum. ${ }^{28}$ In Asia Minor excavations, on the other hand, Pergamon (4), Sardeis (4), Sagalassos (2), Kyzikos (1), Mamurt Kale (Bergama) (1), Tarsus Gözlükule (1), Aizanoi (1) and Amasya-Oluzhöyük (1) are the sites where specimens were found. ${ }^{29}$ )

\section{Uncertain Western Asia Minor}

c. $323-310$ BC.

Obv. Macedonian shield with head of Herakles $3 / 4$ left

Rev. B-[A]. Macedonian helmet, wheat ear in left below

Price 1991, n. $2806^{30}$

26 I would like to thank Z. Çizmeli-Öğün for sharing the excavation data with me.

27 Şimşek 2011.

28 Ashton 1998: 40, n. 117-119.

29 Pergamon: Regling 1913: 355-363; Regling 1914: 5671-5685, also see Çizmeli Öğün-Marcellesi 2011: 306-308; Sardeis: Bell 1916; Evans 2018: 123, n. 18.13; Sagalassos: I would like to thank Johan Claeys who shared with me the excavation data up to year 2012.; Kyzikos: Köker 2003: 385-392, also see. Çizmeli Öğ̈̈n-Marcellesi 2011: 301-302; Mamurt Kale: Regling 1911: 41-43, also see. Çizmeli Öğün-Marcellesi 2011: 310; Tarsus-Gözlükule: Cox 1950: 38-83; Aizanoi: Köker 2013: 133-151; Amasya-Oluzhöyük: Öztürk 2017: 320, n. 13.

30 According to corrections made by Hersh (1998: 143), Price 2806's denomination should be $1 / 2$ AE instead of 
Ashton 2004, 33-43 (Kaunos, c. 323-310 BC.)

9. $1 / 2 \mathrm{AE} 16 \mathrm{~mm}, 3.55 \mathrm{gr}, 12 \mathrm{~h}$,

Inv. No. 2012-10 (Purchased) Rev. B-[A]

10. $1 / 2$ AE $16 \mathrm{~mm}, 3.19 \mathrm{gr}, 1 \mathrm{~h}$

Inv.No. 2012-5 (Purchased) Rev. B-[A]

(Note: These coins, which are classified by Price (1991) under the title "Uncertain Western Asia Minor", were attributed to Kaunos by Ashton (2004) based on 11 specimens in Fethiye Museum and 1 coin from KaunosTelmessos region. It has not been found in Kaunos excavations yet. 2 specimens were found in Nif Mountain Karamattepe excavations. ${ }^{31}$ There are 14 specimens in İzmir Archaeology Museum, 2 in Afyon Museum, ${ }^{32}$ 1 in Ankara Museum of Anatolian Civilizations and 1 in Alanya Museum.)

\section{Modern-day imitation}

\section{Salamis}

c. $332-323$ BC.

Obv. Head of Herakles r., in lion skin

Rev. A $\Lambda$ EEAN $\triangle P O Y$. Zeus enthroned left, holding eagle on extended right hand and resting left on scepter, bow in left field

Price 1991, n. 3141

11. AR $12 \mathrm{~mm}, 0.98 \mathrm{gr}, 12 \mathrm{~h}$

Inv. No. 2012-55 (Confiscated)

(Note: This coin is quite likely a modern-day forgery. While the style of the coin raise doubts about its genuinity, the mismatch between the weight of this coinage and the standard weight of its denomination strengthens the suspicion)

\section{Byblos}

c. $330-320$ BC.

Obv. Head of Herakles r., in lion skin

Rev. $A \Lambda E \Xi A N \triangle P O Y$. Zeus enthroned left, holding eagle on extended right hand and resting left on scepter, $A$ in left field

Price 1991, n. 3426

12. AR $28 \mathrm{~mm}, 16.63 \mathrm{gr}, 12 \mathrm{~h}$

Inv.No. 2014-12 (Purchased)

\section{Mylasa}

315-313 BC.

Obv. Three overlapping shields

AE, and head of Herakles is $3 / 4$ right instead of $3 / 4$ left. 31 See. Lenger 2013b.

32 Aston 1998: 40, n. 124-125.
Rev. EUPO $\triangle$ EMOY. Sword in sheath, $\overparen{P}$ in left field

Thompson 1981, p. 212 (Mylasa)

Ashton 1998, p. 33, n. 326-332 (Kaunos?)

13. AE $19 \mathrm{~mm}, 5.18 \mathrm{gr}, 12 \mathrm{~h}$

Inv. No. 2013-30 (Purchased)

\section{Ake}

$306 / 305$ or $305 / 304 \mathrm{BC}$.

Obv. Head of Herakles r., in lion skin

Rev. A $\Lambda E \Xi A N \triangle P O[Y]$. Zeus enthroned left, holding eagle on extended right hand and resting left on scepter, [.] $Y \mathrm{O}$ in left field

Newell 1916, n. 50-51

Price 1991, n. 3301-3302

14. AR $27 \mathrm{~mm}, 16.50 \mathrm{gr}, 9 \mathrm{~h}$

Inv. No. 2014-11 (Purchased)

\section{Barbarous Imitation}

Obv. Head of Herakles r., in lion skin

Rev. A $\Lambda$ E $\triangle A N \triangle P O Y$. Zeus enthroned left, holding eagle on extended right hand and resting left on scepter, symbol illegible in left field

15. AR $27 \mathrm{~mm}, 16.89 \mathrm{gr}, 11 \mathrm{~h}$

Inv. No. 2014-13 (Purchased)

\section{Kingdom of Lysimachus}

\section{Cius}

Late 260s-250s BC.

Obv. Head of Alexander the Great to right, wearing horn of Ammon

Rev. $\Lambda$ Y $\Sigma$ IMAXOY BA $\Sigma \mathrm{I} \Lambda \mathrm{E} \Omega \Sigma$. Athena enthroned to left, holding Nike and resting left arm on shield, club and $M$ in left field, quiver and $A$ in exergue

Müller 1858, n. 413; 418 (Erythrai)

Marinescu 2017, Issue 20, n. 53-94

16. AR $30 \mathrm{~mm}, 16.52 \mathrm{gr}, 11 \mathrm{~h}$

Inv. No. 2014-14 (Purchased)

(Note: This coin was attributed by Müller to Erythrai in Ionia. M. Thompson, based on E. T. Newell's unpublished work on the subject, attributed these coins to Cius without specifying the reasons. ${ }^{33}$ Marinescu, reviewing the unfinished writings of E. T. Newell, presents us with Newell's proposal which is based on the examination of

33 Thompson 1968. 
symbols used as well as a comprehensive die study. ${ }^{34}$ )

\section{Seleucid Kingdom \\ Antiochus II Theos \\ Sardeis}

261-246 BC.

Obv. Laureate head of Apollo right

Rev. ANTIOXOY BA $\Sigma I \Lambda E \Omega \Sigma$. Tripod, $\mathrm{A}$ in right field, anchor in exergue

SC, n. 522(4)

17. AE $16 \mathrm{~mm}, 4.55 \mathrm{gr}, 12 \mathrm{~h}$

Inv. No. 2015-4 (Donation)

\section{Seleucus II Callinicus}

\section{Sardeis}

246-242 BC

Obv. Head of Athena right in crested helmet

Rev. BA $\Sigma \mathrm{I} \Lambda \mathrm{E} \Omega \Sigma \Sigma \mathrm{E} \Lambda \mathrm{EYKOY}$. Apollo standing left, Ko in left field, $A$ in right field

$\mathrm{SC}$, n. 660(5) (Monogram variety)

18. AE $18 \mathrm{~mm}, 4.50 \mathrm{gr}, 12 \mathrm{~h}$

Inv. No. 2016-38 (Purchased)

Seleucus II Callinicus

Uncertain Ming 43, Western

246-226 BC.

Obv. Head of Athena right in crested helmet

Rev. [BA $\Sigma \mathrm{I} \Lambda \mathrm{E} \Omega \Sigma \Sigma \mathrm{E} \Lambda \mathrm{EYKOY}$ ]. Apollo standing left, $\mathrm{K}$ illegible

SC, n. 733

19. AR $18 \mathrm{~mm}, 3.30 \mathrm{gr}, 12 \mathrm{~h}$

Inv. No. 2014-43 (Purchased)

\section{Antiochus III Megas}

\section{Sardeis}

197-187 BC

Obv. Laureate head of Apollo right

Rev. ANTIOXOY BA $\Sigma I \Lambda E \Omega \Sigma$. Apollo standing left, resting elbow on tall tripod

SC, n. 983(6)

20. AE $15 \mathrm{~mm}, 3.46 \mathrm{gr}, 11 \mathrm{~h}$

Inv. No. 2016-7 (Donation)

34 Marinescu 2017: 178
Rev. [ANTIOXOU] BA $\Sigma \mathrm{I} \Lambda$ E $\Omega[\Sigma]$

21. AE $13 \mathrm{~mm}, 4.16 \mathrm{gr}, 12 \mathrm{~h}$

Inv. No. 2013-44 (Donation)

Rev. ANTIOX[OY] BA $\Sigma \mathrm{I} \Lambda \mathrm{E}[\Omega \mathrm{S}]$

\section{Antiochus III Megas \\ Antioch on the Orontes \\ 223-187 BC. \\ SC, n. 1051 \\ 22. AE $16 \mathrm{~mm}, 3.99 \mathrm{gr}, 12 \mathrm{~h}$ \\ Inv. No. 2013-45 (Donation) \\ Unidentified Coins}

Obv. Laureate head of Antiochus III right

Rev. ANTIOXOY $[\mathrm{BA}] \Sigma \mathrm{I} \Lambda \mathrm{E} \Omega[\Sigma]$. Apollo standing left, resting elbow on tall tripod, I left field, above 姜

\section{Antiochus II?}

\section{Phokaia?}

261-246 BC.

Obv. Head of Antiochus I? right

Rev. [ANTIO]XOY [BA $\Sigma] \mathrm{I} \Lambda \mathrm{E} \Omega \Sigma$. Apollo seated left on omphalos

Cfr. SC, n. 513

23. AR $17 \mathrm{~mm}, 3.83 \mathrm{gr}, 9 \mathrm{~h}$

Inv. No. 2012-54 (Donation)

\section{Ptolemaic Kingdom}

Ptolemy I Soter

Palai Paphos (Probably with Nea Paphos)

From 294 BC.

Obv. Head of Aphrodite right, wearing stephane

Rev. [II]TO $\Lambda$ [EMAIOY]. Eagle standing left on thunderbolt, spread wings

Svoronos, n. 79 (Cyprus, In the name of Ptolemy, 310305 BC.)

CPE, n. B119

24. AE $16 \mathrm{~mm}, 2.98 \mathrm{gr}, 1 \mathrm{~h}$

Inv. No. 2013-41 (Confiscated)

\section{Ptolemy II Philadelphus}

\section{Alexandria}

From 275/274 BC.

Obv. Laureate Head of Zeus right 
Rev. IITO $\Lambda$ EMAIOY BA $\Sigma \mathrm{I} \Lambda \mathrm{E} \Omega \Sigma$. Eagle standing left on thunderbolt, spread wings, illegible letter/monogram between legs, shield in left field, above it $\Sigma$

Cfr. Svoronos, n. 553; 556; 560; 563; 568; 571; 576; 580; 586; 593; 598; 600

Cfr. CPE, n. B166; B168; B170; B172-B175; B177-B181 (Bronze diobol)

25. AE 27 mm., 16.55 gr., 12h

Inv. No. 2013-39 (Confiscated)

Rev. IITO $\Lambda$ EMAIOY BA $\Sigma I \Lambda E \Omega \Sigma$

26. AE 27 mm., 15.44 gr., $12 \mathrm{~h}$

Inv. No. 2013-38 (Confiscated)

Rev. [IITO $\Lambda$ EMAIOY [BA $\Sigma \mathrm{I} \Lambda \mathrm{E} \Sigma \mathrm{S}]$

\section{Ptolemy II Philadelphus}

\section{Alexandria}

260s BC.

Obv. Laureate Head of Zeus right

Rev. IITO $\Lambda$ EM[AIOY] [BA $\Sigma I \Lambda E \Omega \Sigma]$

Eagle standing left on thunderbolt, spread wings, $\Lambda$ between legs, shield in left field, above it $\Sigma$, below it

Svoronos, n. 581 (Cyprus, 275 BC.)

Picard-Faucher 2012, n. 164-166

CPE, n. B190

27. AE $26 \mathrm{~mm}, 13.31 \mathrm{gr}, 12 \mathrm{~h}$

Inv. No. 2013-37 (Confiscated)

\section{Ptolemy III Euergetes}

\section{Probably Kaunos}

246-222 BC.

Obv. Horned Head of Zeus Ammon right, wearing taenia Rev. [IITO $\Lambda$ EM]AIOY BA $\Sigma I \Lambda E \Omega \Sigma$. Eagle standing left on thunderbolt, closed wings, trident in left field

Svoronos, n. 839 (Ptolemy II Philadelphus, Berytos, 285-246 BC)

CPE, n. B434

28. AE $16 \mathrm{~mm}, 2.95 \mathrm{gr}, 12 \mathrm{~h}$

Inv. No. 2016-14 (Donation)

\section{Ptolemy III Euergetes}

\section{Probably Kaunos}

246-222 BC.

Obv. Horned Head of Zeus Ammon right, wearing taenia Rev. [IITO $\Lambda$ EMA]IOY BA $\Sigma \mathrm{I} \Lambda \mathrm{E} \Omega \Sigma$. Eagle standing left on thunderbolt, closed wings, trident (unclear) in left field Svoronos, n. 840 (Ptolemy II Philadelphus, Berytos, 285-246 BC)

CPE, n. B435

29. AE $13 \mathrm{~mm}, 1.36 \mathrm{gr}, 1 \mathrm{~h}$

Inv. No. 2016-10 (Donation)

\section{Ptolemy III Euergetes}

\section{Telmessos}

246-222 BC.

Obv. Horned Head of Zeus Ammon right, wearing taenia

Rev. IITO $\Lambda$ EMIOY BA $\Sigma I \Lambda E \Omega \Sigma$. Eagle standing left on thunderbolt, closed wings, tripod in left field

Svoronos, n. 791 (Ptolemy II Philadelphus, Ptolemais, c. 271-246 BC.)

CPE, n. B436

30. AE $24 \mathrm{~mm}, 11.73 \mathrm{gr}, 12 \mathrm{~h}$

Inv. No. 2012-7 (Purchased)

31. AE $23 \mathrm{~mm}, 9.80 \mathrm{gr}, 12 \mathrm{~h}$

Inv. No. 2012-9 (Purchased)

\section{Ptolemy III Euergetes}

\section{Telmessos}

246-222 BC.

Obv. Horned Head of Zeus Ammon right, wearing taenia Rev. [IITO $\Lambda$ EMIOY] BA $\Sigma I \Lambda E \Omega \Sigma$. Eagle standing left on thunderbolt, closed wings, tripod in left field

Svoronos, n. 793 (Ptolemy II Philadelphus, Ptolemais, c. 271-246 BC.)

CPE, n. B437

32. AE $17 \mathrm{~mm}, 3.18 \mathrm{gr}, 10 \mathrm{~h}$

Inv. No. 2016-15 (Donation)

\section{Acknowledgement}

I would like to thank D. S. Lenger for suggesting this article subject to me and Panagiotis P. Iossif for helping me with problematic Seleucid coins and sharing his opinions. Also, many thanks to archaeologist Kardelen Yilan who is the responsible for the coins in the museum. 


\section{Bibliography}

AkARCA 1959: A.Akarca, Les Monnaies Grecques de Mylasa, Paris, 1959.

Alten 2015: E. Alten, III. Antiokhos'un Hellenistik Krallilar ve Roma ile Olan Ilişkileri, (Unpublished Master Thesis), Akdeniz Üniversitesi, Antalya 2015.

Ashton 1998: R. H. J. Ashton, "The Coins of the Macedonian Kings, Lysimachos and Eupolemos in the Museum of Fethiye and Afyon", In: A. Burnett - U. Wartenberg - R. Witschonke (Ed.), Coins of Macedonia and Rome: Essays in Honour of Charles Hersh, London 1998, 19-48.

Ashton 2002: R. H. J. Ashton, "The Ptolemaic coins in Fethiye Museum”, Numismatic Circular 110, 2002, 7-12.

Ashton 2004: R. H. J. Ashton, "Kaunos, not Miletos or Mylasa", NC 2004, 33-46.

Bagnall 1976: R. S. Bagnall, The Administration of the Ptolemaic Possessions Outside Egypt, Leiden 1976.

Bell 1916: H. W. Bell, Sardis: Publications of the American Society for the Excavation of Sardis, Vol XI, Coins, Part I, 1910-1914, Leiden 1916.

Bosworth 2005: A. B. Bosworth, Büyük Iskender'in Yaşamı ve Fetihleri: Fetih ve Imparatorluk, Çev. $\mathrm{H}$. Çalıșkan, Ankara 2005.

Callataÿ 2016: F. de Callataÿ, "De quoi les monnaies grecques trouvées en fouilles sont-elles le reflet? Propos diachroniques de methodé", In: F. Duyrat, C. Grandjean (Eds.), Les monnaies de fouille du monde grec (VIe-Ier s. a. C.), 239-261.

Cavagna 2015: A. Cavagna, Monete tolemaiche oltre l'Egitto, Milan.

Cox 1950: D. H. Cox, "The Coins", In: Hetty Goldman (Ed.), Excavations at GözlüKule. Tarsus. Vol 1: The Hellenistic and Roman Periods, Princeton, 38-84.

CPE 2018: C. C. Lorber, Coins of the Ptolemaic Empire, 2 vols. New York.

Çevik 2015: N. Çevik, Lykia Kitabı, İstanbul 2015.

Çizmeli ÖĞüN and MARCELlesı 2011: Z. Çizmeli Öğün, M. C. Marcellesi, "Reseaux d'echanges regionaux en Asie Mineure occidentale: l'apport des monnaies fouilles", BCH Suppl. 53, Paris 2011, 297-342.

Davesne 2002: A. Davesne, "La Circulation Monetaire en Pisidie a L'Epoque Hellenistique", Actes du Ier Congres International sur Antioche de Pisidie, 369-373.

Descat 1998: R. Descat, "La carrière d'Eupolemos, stratège macédonien en Asie Mineure", Revue des Études Anciennes 100/1-2, 1998, 167-186.

Evans 2018: J. D. Evans, Coins from the Excavations at Sardis: Their Archaeological and Economic Context, Coins from the 1973 to 2013 Excavations, Archaeological Exploration of Sardis 13, Cambridge-Massachusetts-London.
FABIANi 2009: R. Fabiani, "Eupolemos Potalou o Eupolemos Simalou? Un nuovo documento da Iasos", Epigraphica Anatolica 42, 2009, 61-77.

Grabowski 2019: T. Grabowski, "The Ptolemies in Asia Minor", In: O. Tekin (Ed.), Hellenistik ve Roma Dönemlerinde Anadolu/Hellenistic and Roman Anatolia, İstanbul 2019, 28-52.

GÜNEY 2017: H. Güney, "Unpublished Coins of the Bithynian Kingdom at Bursa Archaeology Museum" NC 177, 2017, 494-500.

Hammond 1992: N. G. L. Hammond, The Macedonian State: Origins, Institutions, and History, Oxford 1992.

Konuk 2004: K. Konuk, "The Ptolemaic coins in the Bodrum Underwater Archaeology Museum”, In: S. Isager, P. Pederson (Eds.), The Salmakis, Inscription and Hellenistic Halikarnassus, 165-175.

KöKER 2003: H. Köker, "The Greek Coins from the 1952-3 Excavations at Cyzicus", NC 2013, 385-392.

KöKer 2013: H. Köker, “Aizanoi Kazıs1 2011-2012 Y1llar1 Sikke Buluntular1”, In: Elif Özer (Ed.), Aizanoi 2012 Yılı Kazı ve Araştırma Raporları, 133-151, Ankara.

Lenger 2013a: D. S. Lenger, "Salamis'e Atfedilen Makedon Krali Bronzlar Üzerine Bir Değerlendirme", Olba 21, 2013, 371-386.

LENGER 2013b: D. S. Lenger, "Yeni Bulgular Ișı̆̆ında Kaunos'a Atfedilen Makedon Krali Darpları", Adalya 26, 2013, 1-9.

Lenger 2016: D. S. Lenger, "New Evidence for the Western Asia Minor Origin of the Macedonian Royal Bronze Issue Price P2 from Nif Olympos Excavations", Philia 2, 2016, 36-41.

Lenger 2019a: D. S. Lenger, "Patara Kazilarında Bulunan Sikkeler”, In: H. İşan (Ed.), Patara: Kent, Liman, Kült, İstanbul 2019, 394-403.

Lenger 2019b: D. S. Lenger, "Price 419A: A New Attribution in the Light of New Data from Nif

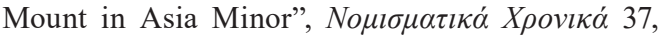
2019, 53-65.

Lenger and TATar 2019: D. S. Lenger, Ö. Tatar, "Not Salamis but Sardes: PRICE 3158 in the Light of İzmir Archaeology Museum Collection and the Archaeological Finds from Nif(Olympos) Mountain in İzmir", Acta Classica Mediterranea 2, 59-77.

Lenger 2021: D. S. Lenger, "Price 2803: Reattribution of a Macedonian Regal Bronze Coin from Western Asia Minor to Tarsus in Cilicia”, Olba 29, 2021, s. 445-456.

Lund 1992: H. S. Lund, Lysimachus: A study in early Hellenistic kingship, London-New York.

Ma 1999: J. Ma, Antiochos III and the Cities of Western Asa Minor, Oxford 1999.

Marinescu 2000: C. Marinescu, "The Posthumous Lysimachi and the Dual Monetary System at Byzantium and Chalcedon," In:XII. Internationaler Numismatischer Kongress Berlin 1997 - Akten, 2000, 333-337. 
Marinescu 2004: C. Marinescu, "From Byzantium to the Black Sea: Dies, Engravers and the Production of Posthumous Lysimachi Coinages during the 3rd2nd c. BC," In: Acta Musei Varnaensis II, 127-138.

Marinescu 2017: C. Marinescu, "The Lysimachi Coinage of Cius, Bithynia”, In: D. Boteva (Ed.), Ex Nummis lux. Studies in Ancient Numismatics in Honour of Dimitar Draganov, Sofia, 177-220.

Meadows 2012: A.Meadows, "6. Deditio in Fidem: The Ptolemaic Conquest of Asia Minor", In: Chr. Smith, L. M. Yarrow (Eds.), Imperialism, Cultural Politics, and Polybius, Oxford-New York, 113-133.

MüLler 1858: L. Müller, Die Munzen Des Thracischen Konigs Lysimachus, Copenhagen.

Newell 1916: E. T. Newell, The Dated Alexander Coinage of Sidon and Ake, New Haven/Oxford.

ÖztüRK 2017: B. Öztürk, “Amasya Oluz Höyük 20092013 Dönemi Kazılarında Bulunan Sikkeler”, Oluz Höyük Kazı Sonuçları Serisi 2, 313-338.

PicARd and FAucher 2012: O. Picard, T. Faucher, "Les monnaies lagides", In: Le monnaies des fouilles $d u$ Centre d'Études Alexandrines: Les monnayages de bronze a Alexandrie de la conquête d'Alexandre à l'Égypte modern, Alexandrie.

Price 1991: M. J. Price, The Coinage in the Name of Alexander the Great and Philip Arrhidaeus. A British Museum Catalogue, Vol. I-II, Zurich-London.

Regling 1911: K. Regling, "Die Antiken Münzen", In: A. Conze - P. Schazmann (Ed.), MamurtKaleh. Ein Tempel der Göttermutter unweit Pergamon, Jahrbuch des Kaiserlich Deutschen Archaologischen Instituts, Erganzungsheft 9, Berlin, 41-43.

Regling 1913: K. Regling, "Verzeichnis der bei den Ausgrabungen von Pergamon gefunden Münzen", Şurada: A. Conze (Ed.), AvP I.2: Stadt und Landschaft, 355-363.

Regling 1914: K. Von Regling, "Münzfunde aus Pergamon", Blatter für Münzfreunde 10/11, 5671-5685.

Robert 1966: L. Robert, Monnaies Antiques en Troade, Paris.

SC 2002: A. Houghton, C. Lorber, Seleucid Coins, A Comprehensive Catalogue: Seleucus I Through Antiochus III, Vol. I, Lancaster- London.

Svoronos 1904-1908: J. N. Svoronos, Ta Nomismata tou Kratous ton Ptolemaion/Münzen der Ptolemaer. 4 vols. Athens, 1904-1908.

ŞimşEK 2011: C. Şimşek, Laodikeia Nekropolü (20042010), Laodikeia Çalışmaları 1.2, İstanbul, 2011.

TATAR 2016: Ö. Tatar, İzmir Arkeoloji Müzesi'nde Bulunan III. Aleksandros ve III. Philippos Dönemine Atfedilen Makedon Krali Bronz Sikkeleri, (Yayınlanmamış Yüksek Lisans Tezi), Akdeniz Üniversitesi, Antalya.
Tekin 2007: O. Tekin, “Sikkeler”, In: S. Durugönül (Ed.), Nagidos, Dağlık Kilikia’da Bir Antik Kent Kazısının Sonuçları, , 193-197.

Thompson 1968: M. Thompson, "The Mints of Lysimachus", In: C. M. Kraay-G. K. Jenkins (eds.), Essays in Greek Coinage presented to Stanley Robinson, 163-182.

Thompson 1981: M. Thompson, "The alexandrine mint of Mylasa", Numismatica e Antichita Classiche 10, 1981, 207-217.

Thompson 1983: M. Thompson, Alexander's Drachm Mints I: Sardeis and Miletus, New York.

WINTERTHUR 1987: H. Bloesch, Griechische Münzen in Winterthur, 1. Spanien, Gallien, Italien, Moesien, Dakien, Sarmatien, Thrakien, Makedonien, Hellas, Inseln, Winterthur.

Wroth 1891: W. Wroth, "Eupolemus”, NC 1891, 135-139.

YAĞız 2014: O. Yağız, "Les monnaies de bronze de Lysimachie de la collection des monnaies grecques du Musée Archéologique de Tekirdağ”, In: K. Dörtlük, O. Tekin, R. Boyraz Seyhan (Ed.), Birinci Uluslararasi Anadolu Para Tarihi ve Numismatik Kongresi, Bildiriler, , 669-684.

YAĞIZ 2016: O. Yağ1z, “Tekirdağ Arkeoloji Müzesi Sikke Koleksiyonunda Yer Alan Doğu Thrak Krallarına Ait Sikkeler”, In: Z. Çizmeli-Öğün (Ed.), KBID 3, 61-74.

Yener 2011: A. Yener, "Elmalı Müzesi”, 20. Müze Çalışmaları ve Kurtarma Kazıları Sempozyumu, 17-30.

Makale Gönderim Tarihi:25.03.2021

Makale Kabul Tarihi: 31.10.2021

\section{ÖMER TATAR}

Orcid ID: 0000-0002-5644-2188

Akdeniz Üniversitesi, Edebiyat Fakültesi, Tarih Bölümü, Eskiçağ Tarihi ABD,

Antalya/TURKEY.

omertatar@akdeniz.edu.tr 


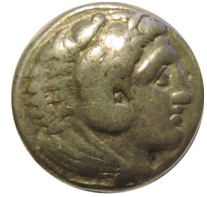

1
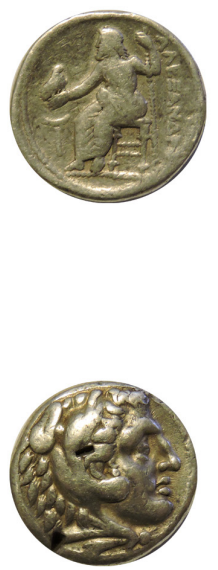

5
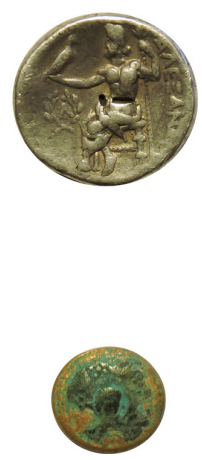

9

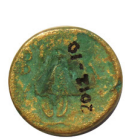

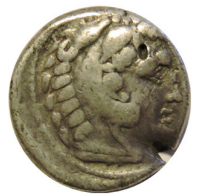

2
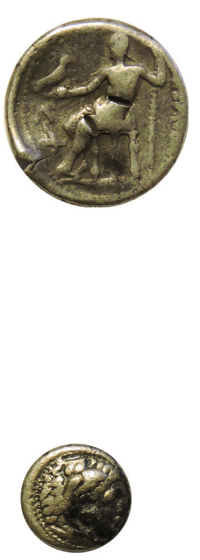

6
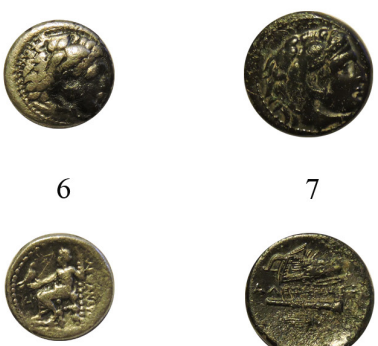

7
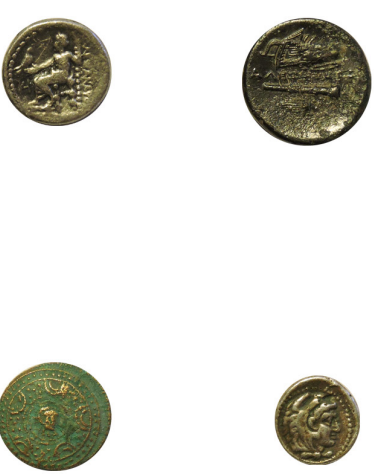

10

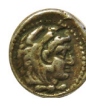

11

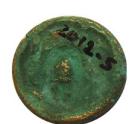

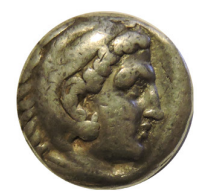

3
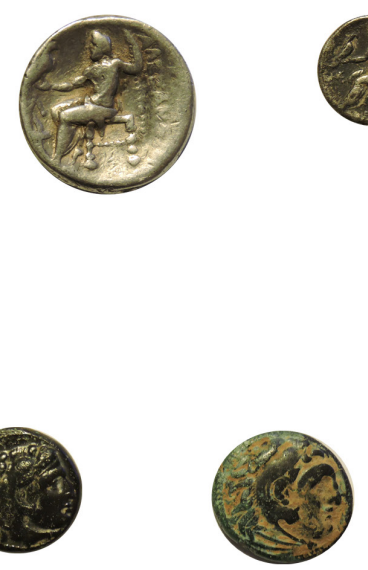

8
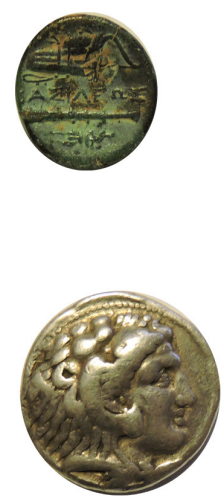

12

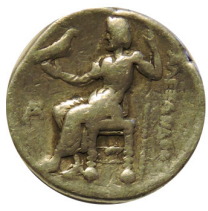

Plate 1. 


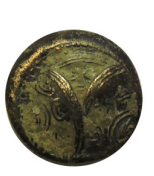

13
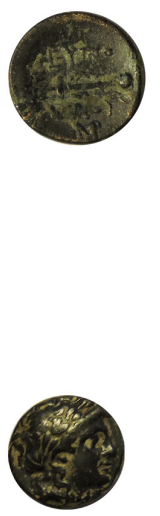

17
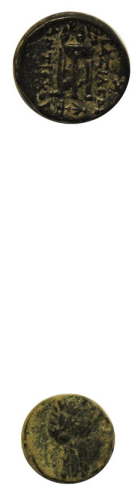

21

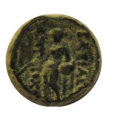

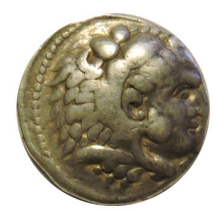

14
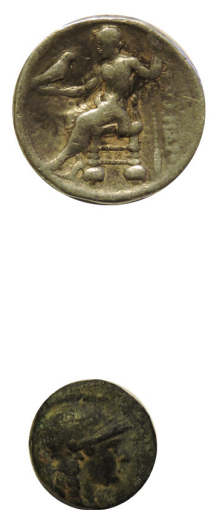

18
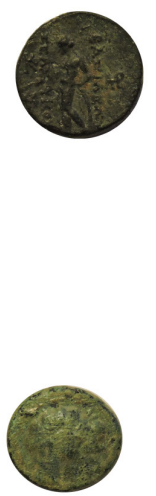

22

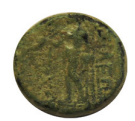

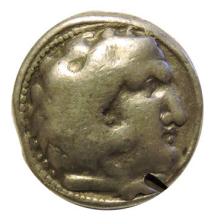

15
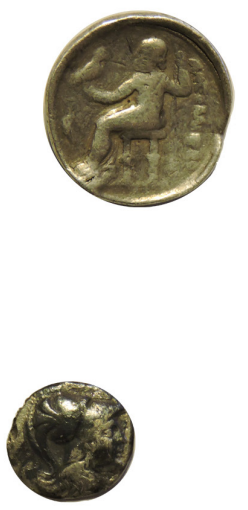

19
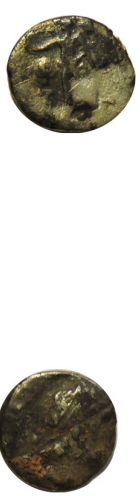

23

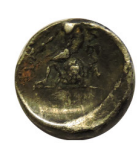

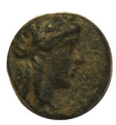

20
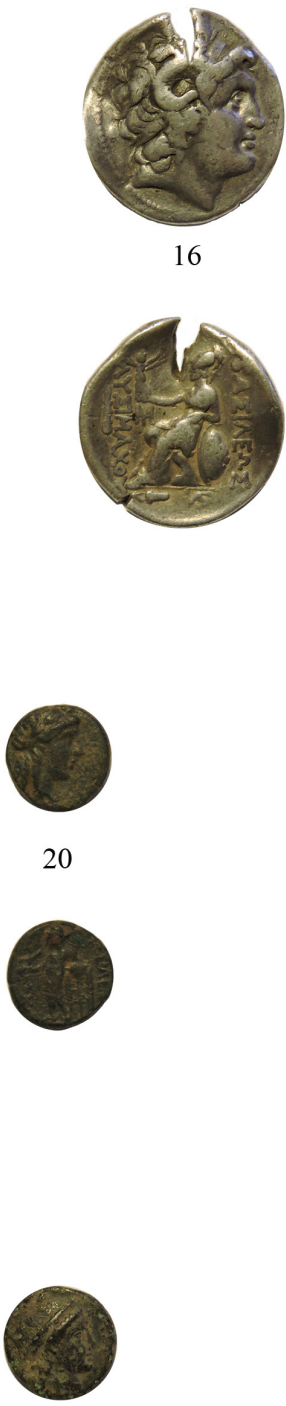

24

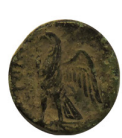

Plate 2. 


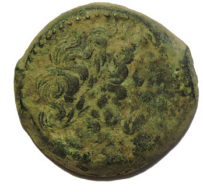

27
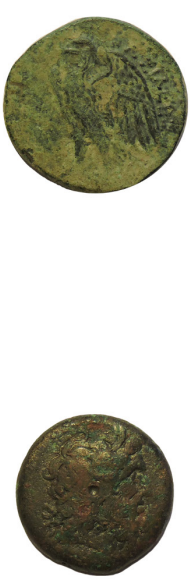

31

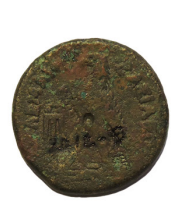

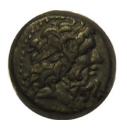

28

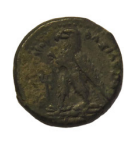

29

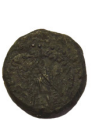

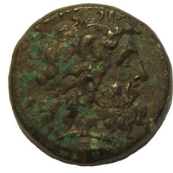

30

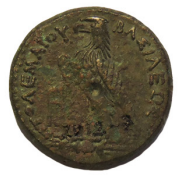

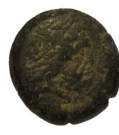

32

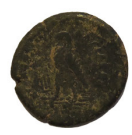

Plate 3. 


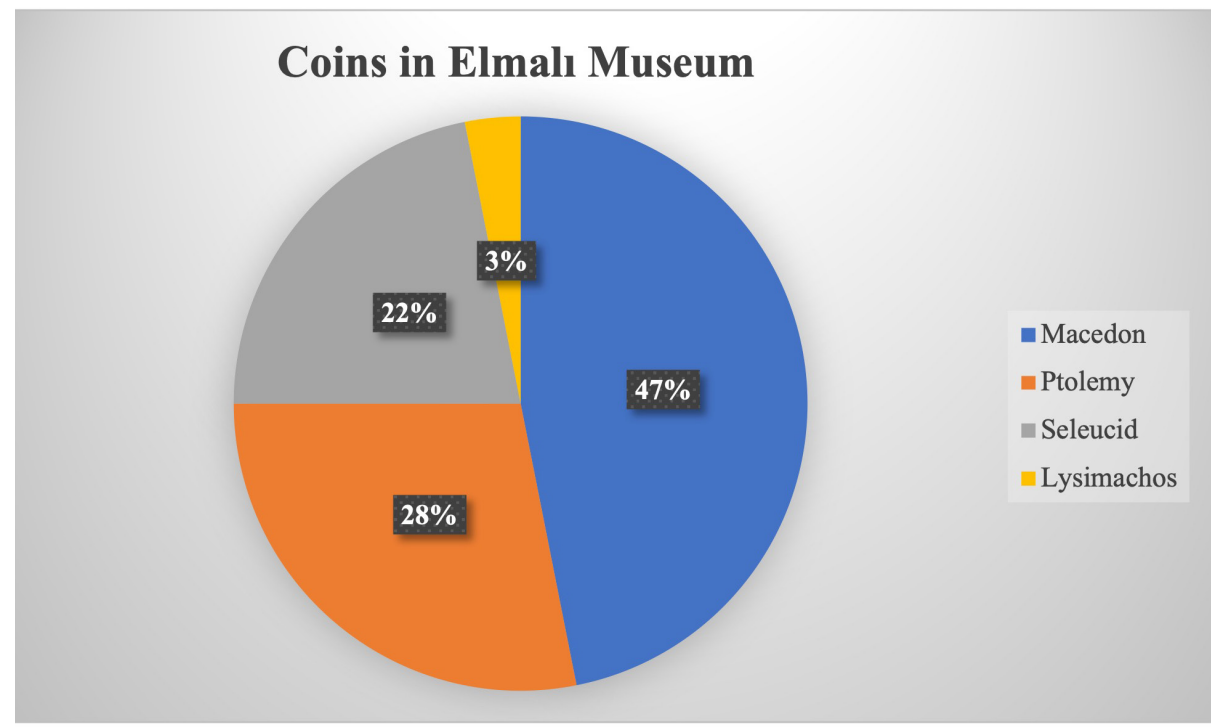

Fig. 1. Statistical analysis of the coins. 